\title{
TUGAS PENYIDIK DI DALAM MELAKSANAKAN PEMERIKSAAN TERHADAP TERSANGKA RESIDIVIS
}

\author{
Oleh : \\ Erly Pangestuti \\ sherly8080@gmail.com
}

\begin{abstract}
Abstraksi:
Indonesia merupakan negara hukum. Hal ini dituangkan di dalam penjelasan Undang-Undang Dasar Negara Republik Indonesia 1945 yaitu bahwa negara Republik Indonesia berdasar atas hukum (Rechstaat), tidak berdasar atas kekuasaan (machstaat). Hukum selalu berkaitan dengan masalah penegak hukum (law enfocement) yang mengarah pada aparat penegak hukum khususnya Polisi Republik Indonesia ( POLRI). Bagaimana optimalisasi peran penyidik Polri dalam melakukan penyidikan terhadap tersangka residivis suatu tindak pidana dan kendala yang dihadapi penyidik dalam menjalankan tugas dan fungsinya sebagai penyidik. Menggunakan metode 1) Bahan Hukum Primer, peraturan perundang-undangan yang berkaitan dengan obyek yang diteliti, 2) Bahan Hukum Sekunder berupa pendapat hukum yang diperoleh dari berbagai sumber dari buku-buku,peraturan undang-undang, jurnal, tesis, artikel / makalah hasil penelitan dan bahan-bahan dari internet yang berkaitan dengan tugas penyidik di dalam melaksanakan pemeriksaan Terhadap tersangka residivis 3) Bahan Hukum Tersier yaitu diperoleh dari Kamus Besar Bahasa Indonesia dan kamus Hukum yang digunakan untuk memperjelas bahan hukum primer dan sekunder.

Penelitian menunjukkan bahwa optimalisasi peran penyidik dalam melaksanakan pemeriksaan terhadap residivis Polri menunjukkan bahwa Penyidik selaku pemeriksa terhadap seorang tersangka dalam hal ini residivis yang sangat pandai dalam hal mengingkari apa yang sudah dilakukannya dengan tujuan supaya mendapat hukuman yang lebih ringan, maka penyidik harus lebih berhati-hati serta memerlukan kesabaran dan mempunyai teknik-teknik khusus untuk mengorek atau menggali keterangan tersangka residivis yang tidak mengakui akan perbuatan yang telah diakukannya. Diperlukan persiapan yang matang untuk penyidik dalam memeriksa tersangka residivis, seperti 1) mental pendidikan yang perlu ditingkatkan, 2) pengiriman bagi penyidik untuk mengikuti pelatihan-pelatihan yang berhubungan dengan pemeriksaan tersangka.
\end{abstract}

Kata Kunci : Tugas Penyidik, Pemeriksaan, Tersangka Residivis. 


\section{A. Latar Belakang Masalah}

Setiap orang yang telah melakukan perbuatan pidana tentunya langkah yang paling utama yang dilakukan adalah dengan panangkapan dan apabila perlu dilakukan penahanan dengan tujuan supaya tidak bisa lari atau menghilangkan barang bukti terjadinya perbuatan pidana, selanjutnya dilakukan pemeriksaan yang dilakukan oleh aparat kepolisian sebagai penyidik adapun yang menjadikan pemeriksaan oleh penyidik sebagai contoh semisal adanya sebuah laporan,pengaduan,tertangkap tangan maupun informasi dari orang lain.

Tugas dari seorang penyidik yang dilakukan oleh aparat kepolisian merupakan tugas yang paling berat,hal ini dikarenakan harus menemukan bukti-bukti maupun saksi disamping itu harus memperhatikan hak-hak tersangka dan dilakukan pemeriksaan sebagai subyek yang mana tidak boleh ditekan dalam pemeriksaan. Di dalam pemeriksaan ini setiap perkara pidana yang dilakukan oleh penyidik dalam hal ini pihak kepolisian tidak boleh seorang tersangka dianggap bersalah sebelum adanya putusan hakim yang mempunyai kekuatan tetap.Oleh sebab itulah dalam pemeriksaan tingkat pendahuluan sangat berhati-hati,hal ini karena nantinya dapat dikatakan melanggar hak asasi manusia (HAM) atau yang lainnya. Disamping itu perkembangan kejahatan yang semakin meningkat apalagi ditengah Pandemi Covid -19 yang tengah melanda Indonesia pada saat ini potensi aksi anarkis dan kriminalitas selalu ada bahkan sangat meningkat, terutama dalam situasi seperti ini. ,membuat aparat kepolisian lebih keras untuk menangani dan memberantasnya.

Untuk memberantas kejahatan serta memprosesnya sampai dengan dipersidangan pengadilan tentunya memerlukan aturan supaya nantinya tidak terkena anggapan di masyarakat bahwa penyidik dalam melakukan pemeriksaan terhadap tersangka telah melanggar hak-hak tersangka,sehingga pada tanggal 31 desember 1981 tentang Kitap Undang-undang Hukum Acara Pidana (KUHAP). 
Keberadaan Kitab Undang-Undang Hukum Aacara Pidana ini telah mengatur hakasasimanusia khususnya tersangka yang lebih melindungi harkat dan martabat manusia yang lebih melindungi harkat dan martabat manusia yang di dasarkan Undang-Undang Dasar 1945 dan pancasila,sehingga seorang penyidik dalam melaksanakan tugas pemeriksaan terhadap tersangka akan sangat berhati-hati.

Dengan adanya aturan Hukum yang menyelesaikan terhadap adanya kejahatan yang terdapat adanya dugaan kejahatan yang terdapat dimasyarakat tidak adanya penyelesaiaan yang dengan cara menghakimi sendiri seperti yang sering kita lihat baik dimasyarakat maupun di media cetak atau elektronik seperti TV, internet sehingga dengan adanya Kitap Undang-Undang Hukum Acara Pidana akan memperlancar adanya pemeriksaan jika terdapat tersangka yang melakukan suatu perbuatan pidana.

Bambang Poernomo,SH yaitu seorang Pakar Hukum. menyatakan bahwa dengan adanya Kitab Undang-Undang Hukum Acara Pidana ini :

"Penerapan satu sisi unsur hukum acara pidana yang mengandung kemanusiaan dan perikemanusiaan bukanlah pekerjaan yang mudah bagi petugas penegak hukum.Biasanya ada anggapan yang keliru bahwa "hukum yang berlaku sudah dengan sendirinya status quo proses hukum pasti dan yang adil",padahal tidak selalu demikian karena realitas dalam realitas dalam masyarakat selalu tumbuh nilai-nilai baru dan perkembangan ilmu kemasyarakatan mempunyai potensi mendorong berlakunya hukum secara dinamis dan praktis."(1988:62)

Dengan adanya tugas penyidik dalam hal ini kepolisian yang sangat berat,maka penulis tertarik untuk membahas dan mengulas mengenai pemeriksaan pendahuluan oleh penyidik terhadap seorang tersangka khususnya residivis dengan memperhatikan hak asasi manusia maupun hakhak tersangka,hal ini karena sekarang ini semakin pandainya tersangka untuk membohongi penyidik apabila diajukan suatu pertanyaan-pertanyaan yang berkaitan dengan kasusnya sangat berbelit-belit. 
Dalam pemeriksaan pendahuluan yang dilakukan oleh seorang penyidik dalam hal ini pihak kepolisian sangat berat,dan pemeriksaan ini merupakan awal daripada pemeriksaan pendahuluan guna untuk proses yang lebih lanjut yaitu dalam proses persidangan sebagai bukti-bukti supaya nantinya dapat dijerat dengan hukuman yang setimpal dengan perbuatannya disamping itu dari sisi lainnya penyidik harus memperhatikan hak-hak tersangka sebagai subyek hukum.

Berkenaan dengan hal tersebut diatas,maka penulis tertarik untuk melakukan penelitian dengan judul Tugas Penyidik Di Dalam Melaksanakan Pemeriksaan Terhadap Tersangka Residivis.

\section{B. Rumusan Masalahan}

Berpedoman dengan latar belakang yang sudah di paparkan diatas t,maka penulis tertarik untuk membahas masalah pemeriksaan yang dilakukan oleh penyidik pada pemeriksaan pendahuluan terhadap tersangka residivis pada perkara pidana yang dalam pemeriksaannya tidak mau mengakui perbuatannya yaitu :

1. Tindakan apa sajakah yang dilakukan seorang penyidik apabila di dalam pemeriksaan tersangka residivis tidak mengakui perbuatannya?

2. Langkah - langkah apa yang dilakukan penyidik terhadaptersangka berkaitan dengan adanya Hak Asasi Manusia?

\section{Tujuan Penelitian.}

Adapaun tujuan dari penelitian ini adalah :

1. Untuk mengetahui apa yang dilakukan oleh penyidik selaku pemeriksa apabila tersangka khususnya residivis tidak mengakui perbutan yang dilakukan.

2. Untuk mengetahi langkah yang dilakukan oleh penyidik terhadap tersangka khususnya residivis yang diperiksa dengan adanya hak asasi manusia. 


\section{Metode Penelitian}

Jenis dan sumber data yang digunakan dalam pelitian ini adalah ;

1. Sumber Hukum

a. Bahan Hukum Primer yaitu merupakan peraturan perundangundangan yang berkaitan dengan obyek yang diteliti.

b. Bahan Hukum Sekunder yaitu berupa pendapat hukum yang diperoleh dari berbagai sumber dari buku-buku,peraturan undangundang, jurnal, tesis, artikel / makalah hasil penelitan dan bahanbahan dari internet yang berkaitan dengan tugas penyidik di dalam melaksanakan pemeriksaan Terhadap tersangka residivis

c. Bahan Hukum Tersier yaitu diperoleh dari Kamus Besar Bahasa Indonesia dan kamus Hukum yang digunakan untuk memperjelas bahan hukum primer dan sekunder.

2. Tehnik Pengumpulan Data

Dalam hal ini tehnik yang dilakukan yaitu dengan menggumpulan data dari bahan-bahan makalah yang berhubungan dengan permasalahan tersebut. Dengan mengumpulkan data-data dari para ahli hukum yang berkaitan denga Tugas para penyidik di dalam melaksanakan pemeriksaan Terhadap tersangka residivis tersebut di harapkan mendapat hasil yang baik.

\section{E. Pengertian Penyidikan Dan Residivis}

Bilamana didapati seseorang yang melakukan perbuatan pidana,maka penyidik harus melakukan pemeriksaan terhadap seorang itu dengan cara penyidikan,hal ini dapat dilakukan dengan siapa saja yang diduga melakukan perbuatan pidana dan penyidik dapat memeriksa sebagai pemeriksa pendahuluan.

Pemeriksaan pendahuluan merupakan awal daripada proses penyelesaian perkara pidana serta sebagai tumpuan untuk untuk tuntutan maupun putusan yang akandiambil baik oleh jaksa maupun oleh majelis hakim,sehingga dalam pemeriksaan pendahuluan yang dilakukan oleh 
penyidik mempunyai tujuan yaitu mencari kebenaran materiil supaya dalam memutuskan suatu perkara nanti tidak salah.

Adapun istilah penyidikan yang berarti mencari kejahatan dan pelanggaran seperti yang diatur dalam pasal 39 HIR,sedangkan dalam pasal 1 angka 2 Kitab Undang-Undang Hukum Acara Pidanayang memberikan pernyataan bahwa yang dimaksud dengan penyidikan adalah serangkaian tindakan penyidik dalam hal dan menurut cara yang diatur dalam undangundang ini untuk mencari serta mengumpulkan bukti yang dengan bukti itu membuat tentang tindak pidana yang terjadi dan guna menemukan tersangkanya.

Tersangka yang melakukan perbuatan pidana dengan sering dan berulang-ulang keluar masuk pemasyarakatan sebagai akibat dari perbuatannnya dapat dikatakan dengan residivis.Residivis ini mmenag sudah berpengalaman dalam hal perbuatan pidana yang dilakukannnya,sehiungga dalam menghadapi seorang penyidik juga berpengalaman.

\section{F. Dugaan Dalam Melakukan Perbuatan Pidana.}

Sebelum penyidik melakukan suatu kegiatan pemeriksaan terhadap seseorang atau lokasi adanya perbuatan pidana,maka seorang penyidik dalam hal ini polisi memerlukan adanya sangkaan atau dugaan bahwa sesuatu perbuatan pidana telah dilakukan. Dengan adanya dugaan permulaan adanya perbuatan pidana tersebut,maka aparat penegak hukum yang berwenang melakukan segera mulai serangkaian pemeriksaan pendahuluan yaitu dengan penyelidikan.

Pemeriksaan ini dilakukan bukan sekedar disasarkan atas dugaan-dugaan belaka,akan tetapi terdapat suatu dasar yang digunakan adalah bahwa penyelidikan bertujuan untuk membuat suatu perkara pidana menjadi terang dengan mengumpulkan bahan-bahan pembuktian mengenai terjadinya perbuatan pidana. 
Adapunyang menjadi dasar seorang penyidik melakukan pemeriksaan pendahuluan diantaranya juga melakukan penyelidikan, maka menurut Maertiman Prodjohamidjojo adalah :

1. Adanya Laporan

2. Adanya Pengaduan

3. Adanya Infortasi

4. Kedapatan tertangkap tangan $(1982: 22)$

Ad.1. Yang dimaksud dengan laporan dalam pasal 1 sub 26 Kitab Undangundang Hukum Acara Pidana adalah sebagai berikut : "Pemberitahuan yang disampaikan oleh seseoranag karaena hak dan kewajibannnya berdasarkan undang-undang kepada pejabat yang berwenang tentang telah atau sedang atau di duga akan terjadinya peristiwa pidana."

Atas dasar laporan ini, maka penyidik atau penyelidik melakukan tindakan-tindakan yang diperlukan yaitu misalnya melihat ke tempat kejadian,memeriksa benda-benda yang ada disekitar tempat kejadian,yang mungkin dapat digunakan petunjuk lainnya sehingga penyidik dapat melakukan pelacaan lebih lanjut.

Ad.2. Adapun yang dimaksud dengan pengaduan yang mana diatur dalam Kitab Undang-undang Hukum Acara Pidana pada pasal 1 sub 25 yaitu : "Pemberitahuan disertai permitaan oleh pihak yang berkepentingan kepada pejabat yang berwenagn untuk menindak menurut hukum seorang yang telah melakukannya."

Untuk melakukan tindakan terhadap seseorang yang melakukan perbuatan pidana yang merupakan delik aduan diharapkan adanya aduan absolut.Disamping itu juga terdapat delik aduan relatif yang sebenarnya yaitu merupayan delik biasa tetapi karena si pelaku itu masih dalam lingkungan keluarga,maka diperlukan aduan.Perbuatan pidana yang merupakan delik aduan ini tidak bisa ditindak aparat penegak hukum tanpa adanya aduan oleh pihak korban. 
Ad. 3. Yang dimaksud dengan informasi adalah mengetahui dengan kebetulan melalui media masa baik cetak maupun elektronika misalkan televisi,radio dan lain-lain lainnya telah akan atau sedang terjadi perbuatan pidana.

Misalkan mendapat informasi dari seseorang atau media cetak atau elektronika bahwa di daerah A telah terjadi perbuatan pidana,maka atas dasar pemberitaan ini melakukan penyelidikan dan mengumpulkan bahan-bahan bukti,keterangan-keterangan, dan petunjuk-petunjuk dan apabila sudah cukup bukti maka mengadakan tindakan pemeriksaan pendahuluan yang dilakukan oleh penyelidik.

Ad.4. Adapun yang dimaksud dengan kedapatan tertangkap tangan berdasarkan pasal 1 butir 19 Kitab Undang-Undang Hukum Acara Pidana adalah :’Tertangkapnya pada waktu sedang melakukan perbuatan pidana,atau dengan segera sesudah beberapa saat tindak pidana,atau dengan segera sesudah beberapa saat tindak pidana itu dilakukan,atau sesaat kemudian diserukan oleh kalayak ramai sebagai orang yang melakukannya,atau apabila diduga kuat telah dipergunakan untuk melakukan tindak pidana itu menunjukkan bahwa ia adalah pelakunya atau turut melakukannnya atau membantu melakukannya tindak pidana itu.

Pemeriksaan terhadap seseorang yang melakukan prerbuatan pidana yang tertangkap tangan, maka penyidik dalam melakukan pemeriksaan terhadap tersangka sangat mudah hal ini di dukung adanya bukti-bukti maupun saksi yang langsung didapatkan pada waktu seorang itu melakukan perbuatan pidana,lain halnya pemeriksaan yang dilakukan terhadap seseorang yang melakukan perbuatannpidana yang kejadiannya sudah beberapa waktu selang lama.

Tindakan penyidik apabila tertangkap tangan adalah berupa tindakan-tindakan seperti yang diatur dalam pasal 5 ayat $1 \mathrm{~b}$ Kitab UndangUndang Hukum Acara Pidana yang isinya bahwa : Penagkapan larangan 
meninggalkan tempat,penggledahan dan penyitaan, pemeriksaan dan penyitaan surat,mengambil sidik jari dan memotret seseorang serta membawa dan menghadap ke penyidik,dalam hal yang demikian penyidik wajib membuat berita acara dan melaporkannya kepada penyidik yang daerah hukumnya tewlah terjadi peristiwa tersebut.Apabila terbukti seseorang yang tertangkap tangan itu adalah perbuatan pidana,maka penyidik melakukan tindakan penahan seperti yang diatur dalam pasal 21 Kitab Undang-undang Hukum Acara Pidana.

Laporan,pengaduan maupun informasi yang diterima atau disampaikan kepda penyidik merupakan hal yang masih nmentah dan perlu diadakan penelitian dan penyaringan dengan seksama apakah perbuatan yang dilakukan benar-benar perbuatan pidana atau dalam artian bahwa apakah perbuatan itu telah melanggar suatu perundang-undangan hukum pidana?

Telah dikemukakan diatas bahwa pemeriksaan yang dilakukan oleh penyidik dalam hal ini polisi pada hakekatnya adalah mencari dan menghimpun bahan-bahan pembuktian bila ada perbuatan pidana. Dengan melakukan pemeriksaan terhadap tersangka penyidik seringkali menjumpai kesulitan karena ulah tersangka yang berusaha untuk menghilangkan jejaknya,hal yang barangkali sudah wajar kalau tersangka melakukan perbuatan yang demikian ini karena tersangka menginginkan bebas atau setidaknya berkurang dalam penjatuhan pidana yang akan dilakukan oleh majelis hakim nantinya.

Pada umumnya untuk mencari atau menghimpun bahan-bahan pembuktian secra sistematik dilakukan melalui proses,sedang menurut R.Susilo terdapat beberapa proses yang harus dilalui yaitu :

1. Informasi (Inggris=Information atau Intertigation, Belanda=Informatie atau Nasporing ), yaitu penyidik mengumpulkan keterangan-keterangan serta bukti-bukti yang terutama dapat diperoleh dengan mengolah tempat kejahatan secara sistematis. Para informan dalam hal ini mempunyai peranan yang sangat penting. 
2. Interogasi ( Inggris = Introgration, Belanda =Verhoor) Yaitu memeriksa atau mendengar keterangan orang yang dicurigai atau saksi-saksi yang juga dapat diperoleh ditempat kejadian.

3.Instrumentarium ( Inggris =Instrumentation, Belanda = Instrumentatie) yaitu pemakaian alat-alat teknik untuk penyidikan perkara,photografi,mikroskop,dan lain-lain ditempat kejahatan dan laboratorium.( $1978: 34-35)$

Adapun bahan-bahan yang dihimpun oleh penyidik dalam pembuktian itu dapat berupa saksi-saksi yang mengetahui perbuatan pidana yang dilakukan oleh seseorang atau berupa benda-benda yang digunakan melakukan perbuatan pidana.Terhadap keterangan tersangka,keterangan saksi dan bahan-bahan pembuktian lainnya,maka sebelum penyidik melimpahkan kepada jaksa atau penuntut umum penyidik melimpahkan kepada jaksa atau penuntut umum penyidik wajib secara obyektif dalam menilai keteranganketerangan dan bahan-bahan pembuktian tersebut atas dasar kebenaran menurut hukum dan mengingat satu dan hal lain kepentingan masyarakat yang perlu dilindungi dari gangguan kejahatan. Selain itu kepentingan negarasebagaimana diwakili oleh pejabat penegak hukum misalkan polisi,jaksa dan hakim.

Jika atas dasar pertimbangan dan pendapat penyidik bahwa pembuktian tidak mungkin dicukupi lagi,maka penyidik harus menghentikan penyidikan. Demikian juga dalam hal peristiwa ternyata bukan merupakan hal kejahatan atau pelanggaran pidana penyidik mernghentikan demi hukum pemeriksaannya dan jika tersangka masih berada dalam tahanan, maka penyidik harus segera melepaskannnya.

\section{G. Penangkapan Dan Penahanan Terhadap Tersangka}

Semakin berkembangnya kriminalitas atau kejahatan yang ada di masyarakat yang membuat sangat resah sehingga tersangka tidak tenang dalam kehidupan sehari-hari, sehingga diperlukan adannya penanganan yang serius terhadap kejahatan tersebut. Dalam penanganan ini diperlukan adanya kerja sama masyarakat dan penegak hukum dan apabila terjadi dugaan 
terhadap seseorang yang telah melakukan perbuatan pidana,maka penyidik segera melakukan penyelidikan untuk mengumpulkan bahan-bahan pembuktian.

Setelah terdapat pembuktian yang cukup adanya pelaku perbuatan pidana,maka penyidik dalam hal ini polisi segera melakukan penangkapan terhadap si pelaku.Penangkapan ini bukan saja kewajiban dari pejabat penegak hukum saja akan tetapi bisa saja dilakukan oleh setiap orang yang telah,sedang atau terjadi perbuatan pidana dan apabila sudah dilakukan penangkapan oleh seseorang yang mengetahui tersebut,maka segera menyerahkan kepada pejabat penegak hukum.

Di dalam pasal 1 butir 20 Kitab Undang-Undang Hukum Acara Pidana memberikan pergertian tentang penangkapan yaitu suatu tindakan penyidik berupa pengekangan sementara waktu kebebasan tersangka atau terdakwa apabila cukup bukti guna guna kepentingan penyidikan atau penentuan dan atau peradilan dalam hal serta menurut cara yang diatur dalam Undangundang.

Setelah dilakukan penangkapan oleh penyidik,maka tahap berikutnya penyidik melakukan penahanan terhadap tersangka.Penahanan yang dilakukan oleh penyidik, maka tahap berikutnya penyidik melakukan penahanan terhadap tersangka.Penahan yang dilakukan oleh penyidik,merupakan hal yang sangat penting untuk kelancaran penyidikan supaya tersangka tidak melakukan perbuatan pidana lagi atau melarikan diri atau menghilangkan bukti-bukti yang dipakai melakukan perbuatan pidana.

Adapun penahanan itu sendiri terdapat dalam pasal 1 butir 21 Kitab Undang-undang Hukum Acara Pidana adalah : Penempatan tersangka atau terdakwa ditempat tertentu oleh penyidik atau penuntut umum atau hakim dan penempatannya, dalam hal serta menurut cara yang diatur dalam undangundang ini.

Hal-hal yang menonjol dalam pembaharuan hukum acara pidana mengenai penangkapan dan penahanan menurut Bambang Poernomo terletak pada : 
1. Penangkapan atau penahanan disyaratkan adanya surat perintah

2. Pembatasan waktu penangkapan atau penahanan,dan apabila jangka waktu tersebut sudah dilampaui bagi tersangka atau terdakwa berhak untuk dilepas dari tahanan demi hukum dan berhak minta ganti rugi.

3. Meningkatkan praktik hukum yang sudah lama berjalan menjadi peraturan mengenahi alternatif jenis penahanan dalam rumah rumah tahanan negara dan penahan kota (1984: 137).

Penahanan yang dilakukan terhadap tersangka atau terdakwa untuk memberikan jaminan hak asasi manusia di dalam Kitab Undang-Undang Hukum Acara Pidana adalah berjangka waktu 1 (satu) hari 24 jam untuk penangkapan berdasarkan bukti permuylaan yang cukup seperti yang diatur dalam pasal 19 ayat 1 Kitab Undang-undang Hukum Acara Pidana.Apabila dalam satu hari tidak terbukti tersangka harus dilepas dan apabila terbukti melakukan perbuatan pidana,maka penahanan terus dilakukan untuk memudahkan adanya pemeriksaan yang dilakukan penyidik disamping tersangkanya tidak ditahan.

Seperti yang diuraikan diatas bahwa terdapat tiga instansi yang dapat melakukan penahanan terhadap tersangka atau terdakwa yaitu :

1. Penyidik atau penyidik pembantu,untuk kepentingan penyidikan yaitu paling lama 20 hari,bila belum selesai penuntut umum dapat memperpanjang 40 hari seperti yang diatur dalam pasal 24 Kitab Undang-Undang Hukum Acara Pidana.

2. Penuntut umum atau jaksa untuk kepentingan penuntutan yaitu paling lama 20 hari dan dapat diperpanjang oleh ketua Pengadilan Negeri 30 hari bila belum selesai seperti yang diatur dalam pasal 25 Kitab Undang-Undang Hukum Acara Pidana.

3. Hakim untuk kepentingan pemeriksaan di pengadilan.

a. Hakim Pengadilan Negeri guna kepentingan persidangan tanggal paling lama 30 hari bila belum selesai dapat diperpanjang oleh 
Ketua Pengadilan Negeri paling lama 60 hari seperti yang diatur dalam pasal 26 Kitab Undang-Undang Hukum Acara Pidana.

b. Hakim Pengadilan Tinggi paling lama penahanannya 30 hari dan dapat diperpanjang oleh ketua Pengadilan Tinggi 60 hari seperti yang diatur dalam 27 Kitab Undang-Undang Hukum Acara Pidana.

c. Hakim mahkamah Agung jangka waktu penahanannya paling lama 50 hari dan dapat diperpanjang oleh Ketua Mahkamah Agung paling lama 60 hari,seperti yang diatur dalam pasal 28 Kitab Undang-undang Hukum Acara Pidana.

Jika kita jumlahkan semua jangka waktu maksimal untuk tahanantahanan yang dapat diperintahkan oleh lima instansi itu, maka kita sampai pada jumlah : $60+50+90+90+110=400$ hari.Dengan demikian maka jumlah waktu penahanan menurut Kitab Undang-Undang Hukum Acara Pidana ada batas waktunya,sedangkan menurut HIR untuk penahanan 20 hari dan bisa diperpanjang 30 hari setiap perpanjangan tak terbatas karena berdasarkan pasal 83 c HIR bila pemeriksaan belum selesai Ketua Pengadilan Negeri dapat memperpanjang sampai selesai persidangan.

Penangkapan maupun penahan diperlukan adanya surat perintah yang syah dari pejabat yang berwenang memberikannya supaya penangkapan maupun penahanan tidak disalah gunakan oleh pejabat yang berwenang menangkap atau menahan.Apabila penangkapan atau penahan terdapat kurang bukti permulaan dalam jangka waktu tertentu yang ditentukan oleh undangundang harus dilepas untuk kepentingan tersangka.

\section{H. Perlindungan Hak asasi Manusia Dalam Hukum}

Kalau kita perhatikan hak asasi manusia pada dasarnya adalah hak yang berakar pada setiap pribadi manusia yang tidak dapat dicabut oleh siapa saja sesama manusia,hal ini karena hak asasi manusia di punyai sejak lahir sebagai pemberian Tuhan Yang Maha Esa. 
Sejak yang sebutkan dalam bukunya Baharuddin Lopa mengenai hak asasi manusia yaitu dalam pasal 12 Universal Declaration of Human Rights yang menetapkan bahwa :

Tidak seorang jua pun dapat diganggu dengan sewenang-wenang dalam urusan pribadinya,keluarganya,rumah tangganya atau hubungan surat menyurat atau kehormatannya dan nama baiknya.Setiap orang berhak mendapatkan perlindungan undang-undang terhadap gangguan atau pelanggaran demikian (1996: 16)

Setiap orang memerlukan perlindungan hukum sebagai kedudukan pedoman prilaku dan juga dapat menentukan supaya hak-hak asasi manusia dapat diakui.Hak asasi manusia tidak begitu saja semua diberkan akan tertapi terdapat batasan dan adapula hak asasi dikurangi misalkan dengan menangkap,menahan sesorang yang disangka melakukan perbuatan pidana.

Perlindungan hak asasi manusia terhadap tersangka maupun terdakwa yang melakukan perbuatan pidana dalam pemerksaan oleh penyidik diperlukan adanya perlindungan sebagai subyek hukum,hal ini karena seorang tersangka atau terdakwa sebelumnya adanya putusan hakim yang mempunyai kekuatan hukum tetap harus dianggap tidak bersalah.

Dari sisi pribadi seseorang perlindungan hak asasi manusia ini banyak yang berpendapat dan menyebutkan hak semata-mata yang sifatnya individualistis.Pandangan seperti itu merupakan pandangan yang kliru sebagai akibat kekurang pahaman sebagai anggota masyarakat terhadap Undang-undang Dasar 1945 dan Pancasila.

Seperti yang dikemukan oleh seorang sarjana yang berpendapat mengenai hak asasi manusia bahwa :

Sebenarnya makna hak asasi yang menjamin individu atas masyarakat sehingga dapat hidup layak dalam suatu sistim yang berlaku.Tidak penting apakah sistimnya liberal,komunal atau integral. Yang penting sistim tersebut mampu memberikan jaminan kepada masyarakat buat hidup secara layak.(Fransisca Sumiyati, $1991: 4$ ) 
Perlindungan hukum bukanlah untuk seorang akan tetapi perlindungan hukum bisa saja diberikan baik untuk individu,masyarakat maupun negara untuk ketentraman dan kedamaian hidup dimasyarakat.Seperti juga dijumpai dalam Kitab Undang-undang Hukum Acara Pidana yang mengatur bahwa seseorang tersangka atau terdakwa dalam pemeriksaan yang dilakukan oleh penyidik harus dihormati sebagaiman orang sebagai subyek hukum berdasarkan prinsip atas praduga tak bersalah.(Presumtion of Innocence).

Dalam penerapan terhadap perlindungan hak asasi manusia dalam hukum acara pidana maupun undang-undang yang lainnya,maka dalam hal tertentu hak asasi manusia ditinggalkan demi kepentingan bersama atau masyarakat seperti menangkap seorang pelaku yang berbuat pidana.

\section{Pemeriksaan Pendahuluan Oleh Penyidik Dengan memperhatikan}

\section{hak-hak tersangka.}

Seseorang yang telah melakukan perbuatan pidana dan penyidik sudah mengumpulkan bukti maupun saksi yang sudah dikumpulkan,maka penyidik harus melakukan penyidikan yang merupakan pemeriksaan pendahuluan.Banyak hal yang perlu diperhatikan dalam pemeriksaan tersangka yang diduga melakukan perbuatan pidana diantaranya hak-hak yang dipunyai tersangka harus diperhatikan.

Adapun hak-hak tersangka yang menjamin hak asasi manusia dalam penyidikan yang diatur di Kitab Undang-undang Hukum Acara Pidana dengan mendapatkan perlakuan secara layak yaitu :

1. Tersangka berhak mendapatkan pemeriksaan oleh penyidik dan selanjutnya ke penuntut umum, ini diatur dalam pasal 50 ayat 1 Kitab Undang-undang Hukum Acara Pidana.

2. Mengetahui apa yang dipersangkakan terhadap dirinya dan dasar persangkakan itu, diatur dalam pasal 51 Kitab Undang-undang Hukum Acara Pidana.

3. Memberi keterangan secara bebas yang diatur dalam pasal 52 dalam Kitab Undang-undang Hukum Acara Pidana. 
4. Dianggap tidak bersalah sebelum adanya putusan hakim yang mempunyai kekuatan hukum tetap,seperti yang diatur dalam pasal 8 Undang-undang No. 14 Tahun 1970.

5. Mendapatkan bantuan hukum yang seluas-luasnya.

6. Berhak mengajukan saksi yang meringankan dirinya (Saksi a de charge)seperti yang diatur dalam pasal 116 ayat 3 Kitab Undang-undang Hukum Acara Pidana.

Hak-hak tersangka atau terdakwa yang sudah diatur dalam undangundang seperti tersebut diatas belum banyak dimengerti oleh tersangka,sehingga berkewajiban bagi penyidik untuk memberitahukan hakhak tersangka pada saat melakukan pemeriksaan.

Pemberitahuan hak-hak tersangka pada waktu pemeriksaan pendahuluan merupakan peluang bagi tersangka untuk menyusun langkah pada waktu pemeriksaan pendahuluan merupakan peluang bagi tersangka akan menunjuk penasehat hukum yang sudah disiapkan.

Pemeriksaan pendahuluan yang perlu adanya penasehat hukum merupakan suatu kontrol terhadap suatu pemeriksaan yang dilakukan oleh penyidik,sedangkan pemeriksaan pada tingkat penyidikan yaitu :

"Pemeriksaan pada tingkat penyidikan dan penyidikan itu merupakan rangkaian sebagian tindakan yang dilakukan oleh polisi Negara Republik Indonesia atau penyidik lainnya sebagai "Pendahuluan"untuk mengungkapkan segala kejadian yang dapat menjadi alasan persangkakan agar lebih kuat bahanbahannya tentang ada suatu tidaknya perbuatan pidana. Proses pemeriksaan yang meliputi penyelidikan dan penyidikan tersebut kiranyadapat dinamakan pemeriksaan pendahuluan yang hasilnya apabila ada alasan untuk menuntut akan dilanjutkan pada pemeriksaan akhir di sidang pengadilan sesuai dengan peristiwanya.(Bambang Poernomo,1985 :15).

Pemeriksaan pendahuluan yang dilakukan oleh penyidik merupakan awal daripada perkara pidana yang hasilnya nanti akan digunakan landasan bagi penuntut umum atau jaksa untuk membuat tuntutan sedangkan bagi 
majelis hakim untuk dasar sebagai putusan yang akan diambil nantinya disidang pengadilan.

Pemeriksaan yang dilakukan oleh penyidik terhadap tersangka yang melakukan perbuatan pidana yang merupakan pemeriksaan pendahuluan perlu deberikan pada tersangka yaitu seperti yang sudah diatur dalam pasal 52 Kitab Undang-undang Hukum Acara Pidana yaitu tersangka dalam memberikan keterangan secara bebas tanpa adanya tekanan oleh pihak lain.

\section{J. Pemeriksaan Yang Dilakukan Penyidik Terhadap Tersangka Residivis} Yang Tidak Mengakui Perbuatannya .

Pada waktu pejabat penegak hukum memperoleh informasi ataupun tahu terjadi perbuatan pidana, maka penyidik dalam hal ini polisi langsung mendatangi tempat kejadian perkara ( TKP ) untuk melihat secara langsung dan mencari bukti maupun saksi sebagai awal daripada pemeriksaan. Pemeriksaan yang dilakukan oleh penyidik dalam hal ini polisi tidak memilah-milah apakah yang berbuat pidana itu anakanak,remaja,tua maupun muda serta tidak membedakan suku maupun agamanya.

Perbuatan pidana yang dilakukan oleh seseorang itu terdapat beberapa macam diantaranya ada yang berbuat Cuma satu kali langsung ketangkap dan ada yang berbuat satu kali langsung ketangkap dan ada yang berulang-ulang kali sampai masuk penjara.Perbuatan pidana yang demikian tersebut yang sangat meresahkan masayrakat maupun aparat penegak hukum dalam hal ini pihak penyidik.

Seorang yang melakukan perbuatan pidana dengan berulangulang,maka tentunya lebih propesional lebih-lebih dalam menghadapi penyidik akan lebih berpengalaman, sehingga kemungkinan besar seorang yang sudah berpengalaman ini dalam pemeriksaan akan tidak memberikan keterangan yang sesungguhnya.

Dalam hal seseorang penyidik melakukan pemeriksaan terhadap tersangka yang sering masuk lembaga kemasyarakatan karena perbuatan 
pidana lebih sulit daripada seorang pelaku perbuatan pidana hanya sekali,hal ini karena tersangka bisa tidak mengakui perbuatan yang dilakukan sedangkan penyidik dalam melakukan pemeriksaan sangat berhati-hati karena untuk menghindari adanya pelanggaran hak asasi tersangka seperti yang tercantum dalam pasal 52 Kitab Undang-undang Hukum Acara Pidana yang isinya bahwa seorang tersangka dalam melakukan pemberian keterangan pada penyidik dilakukan dengan bebas dan tidak terdapat tekanan siapapun.

Pemeriksaan tersangka khususnya residivis memang sangatlah sulit, sehingga langkah pertama yang ditempuh penyidik terhadap seorang yang melakukan perbuatan pidana yang melakukan perbuatan pidana di lingkungan Polres Tulungagung yaitu langkah pertama dengan melakukan perampasan kemerdekaan tersangka dengan menahan. Penahanan ini untuk menghindari seorang tersangka melakukan perbuatan pidana lagi,menghilangkan barang bukti yang digunakan melakukan perbuatan pidana serta untuk menghindari seorang tersangkka melarikan diri seperti yang diatur dalam pasal 1 bagian ke 21 Kitab Undang-undang Hukum Acara Pidana.

Apabila penyidik dalam melakukan pemeriksaan tersangka tidak mau mengakui perbuatannya ,maka penyidik memperlihatkan barang bukti yang sudah didapat pada waktu penyidikan pada tempat kejadian atau mempertemukan saksi-saksi yang mengetahui adanya perbuatan pidana yang dilakukan oleh tersangka.

Dalam pemeriksaannya memang lebih sukar karena biasanya tersangka berbelit-belit dalam memberikan jawaban dari pertanyaanpertanyaan dari penyidik, hal ini karena menghindari penjatuhan pidana oleh hakim lebih berat kalau mengakui perbuatannya semuanya. 


\section{K. Langkah-langkah Yang Dilakukan Oleh Penyidik Terhadap Tersangka Yang Diperiksa Dengan Adanya Hak Asasi Manusia.}

Hak Asasi Manusia sebagai seperangkat hak dasar atau hak pokok manusia yang sebenarnya telah dibawa sejak lahir sebagai anugerah dari Tuhan yang wajib dilundungi dan dihargai setiap manusia guna melindungi harkat dan martabat setiap manusia. Interpretasi hak ini terdapat dalam Pembukaan UUD 1945 alinea kesatu yang menyatakan bahwa " kemerdekaan adalah hak segala bangsa ". Pernyataan tersebut terkandung pengakuan secara yuridis hak asasi manusia. Pengakuan hak asasi manusia tertuang pula pada Pasal 1 Deklarasi Universal Hak-hak Asasi Manusia dalam sidang Majelis Umum PBB tahun 1948.

Banyak hal-hal yang dilakukan oleh penyidik dalam hal ini polisi sebagai pemeriksa awal atau pemeriksaan pendahuluan ada seorang yang melakukan perbuatan pidana. Pemeriksaan pendahuluan ini sebagai dasar seorang jaksa memberikan tuntutan pidananya dan majelis hakim akan memberikan putusan.

Pemeriksaan yang perlu diperhatikan oleh penyidik yaitu tersangka harus diperhatikan sebagai subyek hukum dan hak-hak asasinya harus juga dihormati,hal ini karena sebelum Kitab Undang-undang Hukum Acara Pidana yang dipakai sekarang ini memakai HIR yang mana seorang yang diperiksa oleh penyidik dilakukan sebagai obyek hukum dan sering hak asasinya dilanggar seperti disiksa untuk mengakui perbuatannya.

Dalam pemeriksaan yang dilakukan seorang tersangka oleh penyidik maupun penyidik pembantu . Dengan terbatasnya anggota penyidik maupun penyidik pembantu yang tidak seimbang dengan layaknya kasus yang terjadi secara tidak langsung akan berpengaruh terhadap penyidikan itu sendiri.Disamping itu juga berpengaruh terhadap penyidik seorang tersangka yang pendidikannnya lebih tinggi dari penyidik bahkan tersangkanya sedikit mengertitentang hukum.

Dengan latar belakang pendidikan,minimnya penyidik pembantu sangat berpengaruh adanya pemeriksaan tersangka misalkan penyidik 
melakukan pemeriksaan residivis yang dalam melakukan pemberian keterangan sangat berbelit-belit,sehingga akan juga memancing emosi maupun jengkel penyidik itu sendiri.Apabila terjadi hal demikian maka pemeriksaan akan ditunda untuk menghindari supaya tidak melanggar hak asasi tersangka..

Disamping seorang penyidik menunda pemeriksaan tersangka apabila terjadi emosi pada waktu memeriksa,maka langkah yang diambil oleh penyidik untuk mengorek keterangan terhadap tersangka residivis yaitu dengan cara pendekatan-pendekatan secara pribadi.Apabila dirasa sudah tidak ada emosi pada diri penyidik,maka pemeriksaan dapat dilakukan kembali.

Langkah-langkah yang diambil oleh penyidik dalam melakukan pemeriksaan pada tersangka yang melakukan perbuatan pidana setidaknya dapat mendekati apa yang diharapkan oleh undang-undang dalam menghormati hak asasi manusia khususnya tersangka seperti yang diatur dalam pasal 52 Kitap Undang-undang Hukum Acara Pidana.

\section{Kesimpulan}

Untuk mempermudah dalam pemahaman yang ada dalam karya tulis ini, dapat disimpulan mengenai penyidik dalam ini dikaitkan dengan tersangka dan hak asasi manusia dalam hal hak tersangka dari bab-bab maupun sub bab yang sudah penulis uaraikan diatas yaitu:

1. Dalam melakukan pemeriksaan tindakan yang diakukan oleh penyidik, sebagai langkah awal dari serangkaian penyelesaian perkara pidana hendaknya seorang penyidik lebih berhati-hati apalagi tersangka adalah seorang residivis yang sudah berpengalaman menghadapi penyidik.Sebelum melakukan pemeriksaan terlebih dahuluh penyidik harus mengumpulkan cukup bukti dan para saksi-saksi. Bila perlu untuk kepentingan pemerisaan oleh penyidik,tersangka ditahan supaya tidak melakukan perbuatan pidana yaitu menghilangkan barang bukti atau melarikan diri. Untuk menghormati tersangka denga adanya hak-hak 
yang diberikan tersangka dalam undang-undang atau demi pemeriksaan yang tidak melanggar pasal 52 Kitab Undang-undang Hukum Acara Pidana ,maka seorang yang melakukan perbuatan pidana diperlukan adanya penasehat hukum yang mendampingi setiap pemeriksaan.Memang dalam melakukan pemeriksaan terhadap tersangka residivis atau sering sudah melakukan perbuatan pidana, hal ini karena tersangka tidak melakukan perbuatannya semua yang dilakukan oleh karena itu penyidik perlu adanya teknik khusus untuk mengorek tersangka.Apabila tersangka tidak juga mengakui perbuatannya penyidik tetap mengajukan bukti maupun saksi dan yang membuktikan bersalah atau tidak nanti hakim lah yang memutuskan.

2. Dengan keterbatasan tenaga penyidik maupun penyidik pembantu di dan ketidakseimbangan dengan banyaknya kasus yang perlu diselesaikan membuat penyidik akan merasa jenuh dan mudah emosional,sehingga perlu adanya cara yang dipakai penyidik untuk menghindari pelanggaran hak asasi manusia yang sesuai dengan pasal 18 Undang-undang nomor 39 tahun 1999 tentang hak asasi manusia. Disamping itu terdapat beberapa cara yang dilakukan oleh penyidik pada waktu pemeriksaan tersangka,supaya tindak melanggar hak asasi manusia khususnya tersangka seperti yang diharapkan seperti pasal 52 Kitab Undang-undang Hukum Acara Pidana yaitu apabila dirasa sudah jenuh atau lebih lelah dalam melakukan pemeriksaan,maka penyidik melakukan penundaan dan diperlukan pendekatan-pendekatan

\section{Saran-saran}

Dalam penulisan karya tulis ini banyak hal-hal yang kurang baik,oleh karena itu diperlukan kritik yang membangun bagi para pembaca karya tulis ini, disamping itu penulis akan memberikan saran khusus terhadap instansi yang berhubungan dengan penyidikan terhadap tersangka yaitu :

1. Penyidik selaku pemeriksa terhadap seorang tersangka dalam hal ini residivis yang sangat pandai dalam hal mengingkari apa yang sudah dilakukannya dengan tujuan supaya mendapat hukuman yang lebih 
ringan, maka penyidik harus lebih berhati-hati serta memerlukan kesabaran dan mempunyai teknik-teknik khusus untuk mengorek atau menggali keterangan tersangka residivis yang tidak mengakui akan perbuatan yang telah diakukannya.

2. Diperlukan persiapan yang matang untuk penyidik dalam memeriksa tersangka residivis,seperti mental pendidikan yang perlu ditingkatkan misalkan perlunya pengiriman bagi penyidik untuk mengikuti pelatihan-pelatihan kejuruan atau seminar-seminar yang berhubungan dengan pemeriksaan tersangka yang berbelit-belit waktu dalam pemeriksaan penyidik sudah memahami cara penyelesaiannya.

\section{DAFTAR PUSTAKA}

Bambang Pornomo,Orentasi Hukum Aacara Pidana Indonesia, Amarta Buku,Yogjakarta,1984

\section{Pokok-pokok Tata Acara Peradilan Pidana Indonesia Dalam}

Undang-undang RI. No.8 Tahun 1981, Liberty Yogjakarta ,1985.

Pola Dasar Teori Dan Asas Umum Hukum Acara Pidana, Liberti , Yogjakarta 1988

Baharuddin Lopa, Masalah-masalah Politik Hukum Sosial Budaya Dan Agama Sebuah Pemikiran,Pustaka Sinar Harapan Jakarta, 1996.

Fransisca Sumiyati, Relatifisme Kuitural dan hak-hak manusia, Jayakarta, Senin 3 Juni 1991.

Marzuki,Metologi Riset,Fakultas Ekonomi Universitas Islam Indonesia, Yogjakarta, 1986

Martiman Prodjohamidjojo, Seri Pemerataan Keadilan Tentang Penangkapan Dan Penahanan,Ghalia Indonesia,Jakarta 1982.

R. Susilo,Taktik Dan Teknik Penyidikan Perkara Kriminil,Pelita Bogor, 1978. Jurnal Hukum Magnum Opus Agustus 2018 